for over 20 years was physician (and finally senior physician) to a large hospital for tuberculosis and diseases of the chest. Most carefully hare I read the whole Bill, the memorandum, and nearly all the speeches on the second reading, and the statement by the Chancellor that "there is one part of the Bill that has escaped the attention of every doctor in the land " is incorrect.

Mr. Lloyd George stated that " the doctors proceed in their criticisms on five assumptions, all which are erroneous." cannot say that none have done this, but all those with whom I have discussed the measure in private and at public meetings have most assuredly not done so. They and I have proceeded on the assumption that while some of the profession were opposed to the system of capitation payment, a capitation arrangement is the only workable method; but we suggested that, in the event of a capitation grant being ultimately decided upon, it should be laid down that, seeing that neither capitation nor amount is mentioned in the Bill, the minimum capitation fee for ordinary professional attendance (excluding surgical operations and bacteriological and kindred and allied work) be fixed and stated in black and white in the Bill itself at not less than 10s. $6 d$. per annum, thus leaving it open to increase the amount according to the necessities of particular localities. We have never assumed any attendance on families, but only on individuals. We have advocated some kind of selection by patients of their medical attendants (subject to the latter being willing to attend them) being arranged for, a point absent from the Bill. Mr. Lloyd George, when he was told that free choice of doctor was not mentioned in the Bill, quoted Sec. 14: "Every approved society and Local Health Committee shall for the purpose of administering medical benefit make arrangements with duly qualified medical practitioners for insured persons to receive attendance and treatment to the satisfaction of the Insurance Commissioners from such practitioners." This clause might protect medical men against Friendly Societies if the words "every approved society and" were omitted and the majority of each Local Health Committee and of the Insurance Commission consisted of medical practitioners, but not otherwise. Mr. Lloyd George said that "not a doctor in the country has seen that." Why, Sec. 14 (1) is one of the many points round which the doctors' objections have clustered! He added, "They (the doctors) are free to make any arrangements which they like, which the societies like, of which the Insurance Commissioners approve." Did Mr. Lloyd George think he was speaking to children? How can "they" make the "arrangements" which they like when the Bill, so far, provides for their forming only one-ninth, or at most two-ninths, of the Local Health Committee, onethird of which is to be appointed by the "approved societies" ?

Mr. Lloyd George is seeking to confer advantages on certain classes at the expense of the medical profession, and the members of the profession are not going to submit to this. Mr. Lloyd George said, "There is absolutely nothing presoribed in the Bill which would preclude the doctors from making any of the arrangements which they themselves have been recommending during the past few days." True, nor is there anything "prescribed" in the Bill that will protect their interests in any way, and this is what we complain of, particularly as the members of clubs and benefit societies are, to a certain extent, picked lives, Ior they are medically examined prior to admission and admitted only if medically fit, while the "Post Office" crowd that this Bill would let in might be all diseased at the moment of admission-the Bill says nothing to the contrary.

Later on Mr. Lloyd George clearly showed what his idea of the profession is. He admitted that he had to take some basis for medical attendance. He said, "I took the basis of (6s. because I understood from the report (British Medical Association, 1903) that this was the sum which was better than most doctors ever expected-better than most of them asked for-and I thought at any rate I would be on the right side if I put the amount at $6 s$." What satisfied a group of club doctors whose private practices were left untouched does not necessarily now satisfy a whole profession whose com plete private practices are threatened with ruin by compulsory insurance. If Mr. Lloyd George's speech, from which I have quoted, is to be taken as representing his scheme, the medical profession should simply reply, "It is a hollow and ridiculous sham," and without the coopperation of the medical profession the sham is doomed. The voice of the medical profession as a body calls for a basis not lower than $10 s .6 d$. per head-if there is a capitation payment-and this, too, for only ordinary medical treatment; for a free choice of doctors by patients if the doctors are willing to attend them; perfect independence of all so-called friendly societies; a strong medical proportion on all committees, boards, and on the commission; and all these points to be stated clearly in the Bill itself (and not to be left over "for consideration between next August and April," as Mr. Lloyd George asks -i.e., after the Bill has passed), otherwise Mr. Lloyd George will have difficulty in finding his "best medical attendance." I enclose my card.

I am, Sir, yours faithfully,

M.D., D.P.H., M.R.C.P. LOND. (BARRISTER-AT-LAW). June 17th, 1911.

\section{THE POSITION OF THE PRESENT REFORM MOVEMENT IN ANASTHETICS.}

\section{To the Editor of THE LANCET.}

SIR,-I am very glad to read Mr. H. Nelson Hardy's letter on the above subject in THE LANCET of June 17th, partly because the criticisms it contains are obviously the outcome of a thoughtful study of the subject, and partly because I can, I think, put such considerations before him as will help him to see the points he raises in a somewhat different light. His first point would seem to be that as there are far more anæsthetic fatalities under registered than under unregistered administrators - a fact that is, of course, incontestablethere would be very little gained by the passage of an Act which would only protect the public against the risks of anæsthesia conducted by the latter class of practitioners. The second point, I take it, is that the use of methylated in contradistinction to ethylated or ethyl-alcohol chloroform, introduces a grave risk into chloroform anæsthesia. May I be permitted to deal with these two points separately?

One of the chief contentions of those who have interested themselves in the present reform movement is that, considering the knowledge we now possess as to the physiological and clinical effects produced by anæsthetics, the public is not sufficiently safeguarded against the risks of these agents. It is maintained, in fact, that a large number of the deaths which annually take place during general anæsthesia are preventable. As one fatality after another is chronicled Science seems to say to all whose ears are attuned to her utterances: "Provided anæsthetics are administered by persons whose general and professional education has been such as to entitle them to employ these powerful drugs, and provided also that such agents are adminis tered according to those principles which recent experiment and clinical study have elaborated, the risks of artificially induced unconsciousness will be so slight that no one requiring surgical treatment need hesitate to incur them. But if ignorant and unqualified persons be permitted to take upon themselves these responsibilities, or if properly educated and qualified persons be permitted to use these drugs in such a way as to transgress the laws which are now known to be essential for safe anæsthetisation, painless surgery cannot possibly be practised without incurring grave risks from the necessary anæsthesia." Science bids us indeed put our house in order, and the sooner we begin to do so the better for the safety of the public and for the credit of our profession. The question is, Where shall we begin? Surely we must, in the first place, inspect the whole fabric from basement to attic, and decide whether any alterations of a structural nature are needed in order that the house, when completed, may conform to modern requirements. Should it be found that such structural changes are needed, surely we must start at the very foundations and work upwards. Let us not become the laughing-stock of posterity by repairing and improving the upper floors of our house before looking to these foundations. In other words, let us first see that all anæsthetics are placed in the hands of those who have been sufficiently educated to be entrusted with the responsibilities of anæsthesia ; and when this has been accomplished by legal enactment let us direct our whole attention to improving the conditions under which anæsthetics are administered by registered practitioners. I freely admit that the most radical 
alterations are necessary in the conditions under which anæsthesia is now conducted by those whose right to administer anæsthetics cannot be questioned. But let us deal with irregular practice first, and thus lay the foundation of a new and better order of things for the future.

The second point raised by Mr. Nelson Hardy is whether or not the use of methylated chloroform introduces a risk into chloroform anæsthesia which is absent when ethylated or ethylic alcohol chloroform is used. Mr. Nelson Hardy implies that this is the case, and in support of his thesis be mentions the fact brought to ligbt some years ago that at a certain London hospital where methylated chloroform was used more anæsthetic fatalities had occurred in a certain number of years than at another hospital of about the same size where it was customary to use ethylalcohol chloroform. But if $\mathrm{Mr}$. Nelson Hardy will go more carefully into the matter he will find that there was a far more important difference than this in the conditions under which anæsthetics were administered in these two institutions. In the one in which the larger number of accidents arose no special attention was paid to what may be termed the personal factor in anæsthetising-that is to say, anæsthetics were often entrusted to young and inexperienced administrators. In the other institution, however, in which accidents were far less frequent, anæsthesia was almost invariably conducted either by visiting or by resident anæsthetists. In order, however, that I may more completely dispose of the methylated chloroform bogey, let me add that this particular brand of chloroform is that which I have for some years past recommended for employment in hospitals with which I have been connected, and that at those hospitals at which it has been employed at my recommendation no cases have arisen in which this particular brand seemed in any way responsible for difficulties or accidents. Furthermore, with the object of being consistent and of making myself perfectly certain as to the safety and efficiency of Duncan and Flockhart red label methylated chloroform, I may say that I have myself used this chloroform for the last four years and without any of those results which Mr. Nelson Hardy and the believers in the danger of this brand regard as likely to arise.

June 20th, 1911. I am, Sir, yours faithfully, FreDERIC HEWITT.

\section{INQUEST FOLLOWING A CASE OF " HEALING" BY CHRISTIAN SCIENCE.}

\section{To the Editor of THE LANCET.}

SiR,-Will you permit me to point out a mistake which has crept into your report of the inquest on Miss Nora Bohm, who died under Ohristian Science treatment? It is stated that the lady was living in a Christian Science " nursing home." As a matter of fact, there is no such thing as a Christian Science nursing home, and the house in which the patient was living was simply an ordinary house to which anyone could have gone. May I also say that the practitioner called in a doctor after the patient's death, as that is usual in the circumstances? No Christian Science practitioner imagines that a doctor could, or should, give a certificate when he is called in in this way.

I am, Sir, yours faithfully, FREDERICK DIXON.

Surrey-street, Strand, W.C., June 24th, 1911.

\section{THE ELECTION OF DR. J. A. MACDONALD AS A DIRECT REPRESENTATIVE.}

\section{To the Editor of THE LANCET.}

SIR, - I wish to thank the medical practitioners of England and Wales for choosing me to be their Direct Representative on the General Medical Council at the recent election rendered necessary by the regretted death of Dr. McManus. Immediately after the result of the election was declared I was called upon to attend the session of the Council at which the National Insurance Bill was discussed, and the report upon certain of its medical aspects prepared, which drew from the Chancellor of the Exchequer the reply published in THE LANCET last week. The consideration of the Bill by the British Medical Association in the Representative meeting and the Special Committee has made such great inroads on time and energy that my friends will, I am sure, forgive the delay in returning my thanks; though tardily expressed, my gratitude is none the less sincere.

It shall always be my endeavour to justify the confidence my brother practitioners have shown by electing me to so responsible a position at this critical time.

I am, Sir, yours faithfully,

Taunton, June 26th, 1911.

J. A. MaCdONALD.

\section{THE ADVERTISING OF PATENT MEDICINES.}

To the Editor of THE LANCET.

SIR,-It may seem ungracious if, in thanking you for your kind notice of the motion I made in the recent General Assembly of the Church of Scotland regarding secret remedy advertisements in the monthly magazine of the Church, I venture to encroach upon your space. Will you allow me to correct a wrong impression which your paragraph in last week's issue is likely to leave upon your readers regarding the decision of the Supreme Court of our Church on the matter in question? The Assembly was practically unanimous in adopting a modification of my motion. The committee in charge of the magazine had referred in their report to objec. tions urged against certain forms of advertisement, and had reported a marked loss of income due to their refusal to insert questionable notices. Desirous of making an end of a particular class of these advertisements, which still appear in the pages of the magazine, I moved as follows :-

The General Assembly thank the Committee ...... for their care in regard to the selection of advertisements to be circulated in the magazine, and instruct them to carry their enceavours to that end yet further by excluding all advertisements of secret or patent remedies of a medical or quasi-medical description, in order that the disinterestedness and Christian character of the accredited organ of the Church may be above suspicion in that respect.

Althongh I am sorry to say that some voices were raised in defence of the status quo on financial grounds, by an overwhelming majority my motion, down to the words "ye further" was carried, the Assembly preferring to make its instruction more general than my proposal seemed to suggest, so as to include within its scope other objectionable advertisements also-e.g., of all sorts of bogus bargains.

Permit me to add that I value very highly your words of encouragement. I know you would not willingly do injustice either to the Church I represent or to the committee in charge of its magazine.

June 23rd, 1911.

$$
\text { I am, Sir, yours faithfully, }
$$

William A. Curtis.

Children's Convalescent Home, WestonSUPER-M ARE. - The annual meeting of the subscribers of this institution, which is in connexion with the Royal Hospital for Children, Bristol, was recently held. The medical report stated that during 1910 the children admitted numbered 386 . 359 patients had been discharged during the year, and of these 254 had " recovered," 79 had " much improved," 23 had " improved," and 3 showed no signs of improvement. The financial statement showed that subscriptions and donations had slightly diminished.

The "Congresso Nazionale D'IgIene" AT" TURIN.- This, the first of a series of Congresses to be held in future years at one or other of the great academic or industrial cities of Italy, will be inaugurated on Oct. 5 th and will sit till. the 8 th of that month. The agenda paper is both interesting and opportune, prominent among the subjects to be dealt with being "Malaria," by Professor Negri of Pavia. "Industrial Hygiene," by Professor Bianchini of Bologna; "Disinfectants," by Professor Frassi of Parma; "The Hygiene of Schools," by Professor Bordoni-Uffreduzzi of Milan; "Mediterranean Fever," by Professor Neri ; and articles of diet, such as "Sugar," by Professor Giacosa of Turin; "Milk," by Professor Volpino and Professor De Matteis of the same school; and "Drinking Water," by Professor Abba, Professor Volpino, and Professor Cler, also of Turin. Further information as to the Congress may be had on application to the President, Dr. Luigi Pagliani, professor of hygiene in the local university. 